\title{
Pengaruh Closing Price, Trading Volume Activity, dan Volatilitas Return Saham Terhadap Bid-Ask Spread Pada Perusahaan LQ45 Tahun 2017
}

\author{
Ayu Agustin Ika Pratama, Aris Susetyo \\ Sekolah Tinggi Ilmu Ekonomi Putra Bangsa
}

ayuagustin543@gmail.com

\begin{abstract}
Abstrak
Penelitian ini bertujuan untuk mengetahui pengaruh closing price, trading volume activity, dan volatilitas return saham secara parsial maupun simultan terhadap bid-ask spread perusahaan index LQ45 tahun 2017. Sumber data yang digunakan dalam penelitian ini adalah data sekunder harian. Populasi yang digunakan dalam penelitian ini adalah perusahan yang terdaftar dalam Indeks LQ45 tahun 2017 yang berjumlah 45 perusahaan. Teknik pengambilan sampel menggunakan metode purposive sampling yang menghasilkan jumlah sampel sebanyak 33 perusahaan dan 238 hari sehingga membentuk data panel sebanyak 7854 sampel. Teknik analisis yang digunakan adalah analisis regresi data panel Fixed Effect Model dengan bantuan aplikasi software Eviews 10. Penelitian ini menggunakan analisis regresi linear berganda. Hasil penelitian menunjukkan bahwa : 1) closing price berpengaruh signifikan terhadap bid-ask spread, 2) trading volume activity berpengaruh signifikan terhadap bid-ask spread, 3) volatillitas return saham berpengaruh signifikan terhadap bid-ask spread, dan 4) closing price, trading volume activity, dan volatilitas return saham berpengaruh signifikan terhadap bid-ask spread.
\end{abstract}

Kata Kunci : bid-ask spread, closing price, trading volume activity, volatilitas return saham.

\begin{abstract}
The purpose of this research was to determine the effect of closing price, trading volume activity, and volatility of stock return partially and simultaneously on the bid-ask spread of the LQ45 index in 2017. The data sources used in this study were secondary data in the form of daily data. The population used in this study were companies listed in the 2017 LQ45 Index which amount to 45 companies. The sampling technique was purposive sampling method which resulted total sample of 33 companies and 238 days to form a panel data of 7854 samples. The analysis technique used was panel data regression analysis Fixed Effect Model with the used of Eviews 10 Software. This study used multiple linear regression analysis. The results show that: 1) closing price has a significant effect on the bid-ask spread, 2) trading volume activity has a significant effect on the bid-ask spread, 3) volatility of stock return has a significant effect on bid-ask spread, and 4) closing price, trading volume activity, and the volatility of stock returns have a significant effect on the bid-ask spread.
\end{abstract}

Keywords: bid-ask spread, closing price, trading volume activity, volatility of stock return.

\section{PENDAHULUAN}

Bursa Efek Indonesia (BEI) merupakan pasar modal telah membuat pengelompokan terhadap saham-saham yang terdaftar pada Bursa Efek Indonesia (BEI) ke dalam beberapa kelompok indeks saham, salah satunya adalah LQ 45. Indeks LQ 45 menggunakan 45 perusahaan atau emiten yang tercatat di Bursa Efek Indonesia (BEI) sebagai perhitungannya. Sesuai dengan namanya, Indeks Liquid (LQ) 45, merupakan indeks yang terdiri dari 45 perusahaan yang memiliki tingkat likuiditas tertinggi pada periode tertentu. Indeks LQ 45 merupakan pelengkap Indeks Harga Saham Gabungan (IHSG) karena terdiri dari 45 saham unggulan yang terdapat di Bursa Efek Indonesia (BEI). Berdasarkan hal tersebut, dapat dikatakan bahwa Indeks LQ 45 merupakan intisari dari IHSG dimana pergerakannya baik kenaikan maupun penurunan Indeks LQ 45 diikuti serta sejalan dengan kenaikan atau penurunan IHSG. Sehingga LQ 45 dapat digunakan untuk memonitori pergerakan harga saham yang aktif diperdagangkan.

Pemilihan saham dengan tingkat likuiditas yang tinggi dapat menjadi salah satu pilihan investor untuk memperkecil kemungkinan kerugian, seperti sahamsaham yang berada pada Indeks LQ 45. Saham-saham perusahaan yang menjadi bagian dari Indeks LQ 45 merupakan saham yang telah terseleksi melalui berbagai kriteria. Tidak hanya memiliki tingkat likuiditas yang tinggi, namun saham-saham Indeks LQ 45 juga memiliki kapitalisasi pasar yang besar. Selain itu, nilai transaksi, jumlah hari perdagangan, frekuensi transaksi sahamnya, serta kondisi keuangan yang baik dan prospek pertumbuhan yang bagus juga diperhitungkan (Indonesia Stock Exchange, 2010).

Ketika seorang investor berkeinginan untuk membeli saham, maka broker akan mengajukan harga yang dimintanya. Demikian pula sebaliknya, bila seorang investor berkeinginan untuk menjual saham maka broker akan memberikan harga penawaran. Harga saham diduga mempengaruhi bid-ask spread, karena jika harga saham dinilai terlalu tinggi oleh pasar, jumlah permintaannya akan berkurang. Jika permintaan berkurang, maka akan berakibat saham bersangkutan tidak liquid. Investor tidak akan membeli saham tersebut karena biaya yang semakin tinggi sehingga akan mempengaruhi bid-ask spread 
saham. Sehingga dapat dikatakan bahwa bid-ask spread saham perusahaan ditentukan oleh pialang saham. Pialang akan bersiap membeli atau menjual pada kisaran harga yang sudah ditentukan. Dengan bertindak sebagai perantara antara penjual dan pembeli ini, pialang membuka jalan bagi investor untuk bertransaksi sesuai permintaan.

Pengetahuan tentang bid ask spread sangat perlu bagi investor terutama yang mengharapkan memperoleh capital gain, karena hal ini dipandang sebagai salah satu komponen biaya dalam perdagangan saham. Bid ask spread juga mempunyai pengaruh yang cukup besar dalam bursa saham beberapa negara di mancanegara. Namun, demikian pada umumnya para investor dalam menanamkan investasinya terlihat kurang memperhatikan perilaku bid ask spread, padahal bid ask spread saham memberikan banyak informasi bagi investor tentang return, risiko saham, dan lain-lain (Hartono, 2003:2).

Bursa efek disiapkan untuk membantu pialang dan spesialis lainnya dalam mengkoordinasikan harga penawaran dan permintaan. Harga penawaran adalah jumlah yang bersedia dibayarkan pembeli untuk keamanan tertentu; harga yang diminta adalah jumlah yang diinginkan penjual untuk keamanan tertentu dan selalu sedikit lebih tinggi dari harga penawaran. Perbedaan antara harga bid dan ask adalah apa yang disebut bid-ask spread dan perbedaan ini merupakan keuntungan bagi broker atau spesialis yang menangani transaksi.

Corporate insiders (para pekerja dan manajemen) pada umumnya mempunyai informasi yang lebih baik daripada investor lain tentang kondisi perusahaan saat ini dan prospeknya di masa mendatang. Permasalahan yang muncul di pasar modal, investor dihadapkan pada kondisi ketidak seimbangan informasi atau asimetri informasi, dimana sebagian pelaku pasar/partisipan memiliki informasi yang lebih superior dibandingkan dengan pelaku pasar yang lainnya. Besar kecilnya spread menunjukkan seberapa besar informasi asimeti diantara pelaku pasar. Untuk mengurangi tingkat asimetri informasi tersebut maka pelaku pasar berupaya mendapatkan sinyal tertentu yang dapat dijadikan sebagai informasi untuk mengurangi ketidakpastian yang terjadi. Usaha ini akan menimbulkan biaya informasi.

Adanya informasi asimetris membuat para investor kesulitan dalam membedakan antara perusahaan yang berkualitas tinggi dan berkualitas rendah. Pernyataan para manajer dinilai tidak membawa informasi yang bermanfaat, sehingga hal ini mengakibatkan para investor akan menilai rendah semua saham perusahaan. Kondisi ini dikenal dengan istilah "pooling equilibrium" di mana semua perusahaan baik mempunyai maupun tidak mempunyai prospek pertumbuhan dan keuntungan yang bagus pada masa mendatang, dimasukkan dalam kategori yang sama (Megginson, 2000) dalam Nany, 2003). Prinsip dari teori sinyal ini adalah "actions convey information" yang mengajarkan bahwa setiap setiap tindakan mengandung informasi (Atmaja, 1999) dalam Nany, 2003). Perilaku para manajer dalam memberi sinyal terhadap para investor tersebut tentunya akan mengurangi informasi asimetris yang terjadi, sehingga tindakan tersebut akan menurunkan bid-ask spread saham (Nany, 2003).

Berdasarkan uraian diatas, penulis ingin mengetahui faktor-faktor yang dapat mempengaruhi besar kecilnya bid-ask spread. Sehingga judul penelitian ini adalah "Pengaruh Closing Price, Trading Volume Activity dan Volatilitas Return Saham Terhadap Bid-Ask Spread" Pada Perusahaan di Indeks LQ45 Tahun 2017.

\section{LANDASAN TEORI \\ Indeks LQ45}

Indeks LQ45 adalah indeks yang terdiri dari 45 saham perusahaan go public yang dipilih berdasarkan pertimbangan tingkat likuiditas yang tinggi dan kapitalisasi pasar yang besar serta lolos seleksi dengan beberapa kriteria pemilihan. Indeks LQ45 diluncurkan pada bulan Februari 1997. Sejak diluncurkan pada bulan Februari 1997 ukuran utama likuiditas transaksi adalah nilai transaksi di pasar reguler. Sesuai dengan perkembangan pasar, dan untuk lebih mempertajam kriteria likuiditas, maka sejak reviews bulan Januari 2005, jumlah perdagangan dan frekuensi transaksi dimasukkan sebagai ukuran likuiditas.

Nilai pasar agregat dari saham-saham tersebut meliputi sekitar lebih dari $72 \%$ dari total kapitalisasi pasar di Bursa Efek Indonesia. Nilai agregat ini meliputi sekitar $72,5 \%$ dari total transaksi di pasar regular. Dengan demikian indeks LQ-45 ini memberikan gambaran yang akurat akan perubahan nilai pasar dari seluruh saham yang aktif diperdagangkan di Bursa Efek Indonesia (BEI) (Fakhuddin dan Hardianto, 2001:203).

Untuk dapat masuk dalam Indeks LQ45, suatu saham harus memenuhi kriteria tertentu melewati seleksi utama, sebagai berikut:

1. Masuk dalam urutan 60 terbesar dari total transaksi saham di pasar reguler (rata-rata nilai transaksi selama 12 bulan terakhir).

2. Urutan berdasarkan kapitalisasi pasar (rata-rata nilai kapitalisasi pasar selama 12 bulan terakhir),

3. Telah tercatat di BEI selama paling sedikit 3 bulan.

Selain melihat kriteria likuiditas dan kapitalisasi pasar, indeks LQ45 juga melihat keadaan kondisi keuangan dan prospek pertumbuhan perusahaan. Bursa efek secara rutin memantau perkembangan kinerja masing-masing ke-45 saham yang masuk dalam perhitungan Indeks LQ45. Indeks LQ-45 ini akan ditinjau ulang setiap 3 bulan, dilakukan review pergerakan ranking saham-saham yang akan digunakan dalam perhitungan indeks LQ-45. Penggantian saham dilakukan setiap enam bulan sekali, yaitu pada awal bulan Februari dan Agustus. Apabila terdapat saham yang tidak memenuhi kriteria seleksi, maka saham tersebut dikeluarkan dari perhitungan indeks dan diganti dengan saham lain yang memenuhi kriteria.

\section{Bid-ask Spread}

Dalam sistem lelang kontinyu di pasar modal, harga transaksi ditentukan oleh penawaran (supply) dan permintaan (demand) dari investor. Harga transaksi ditentukan apabila ada pertemuan antara harga penawaran penjualan (ask price) dan harga permintaan pembelian 
(bid price) dari investor (Hartono, 2017:16). Bid price merupakan harga beli tertinggi dimana investor bersedia untuk membeli saham sedangkan ask price merupakan harga jual terendah dimana investor bersedia untuk menjual sahamnya. Bid-ask spread merupakan selisih antara ask price dan bid price. Investor memperoleh keuntungan dari spread kedua harga tersebut (Jones, 2007:108). Oleh karena itu, bid-ask spread dapat dijadikan sebagai cerminan ukuran biaya transaksi saham (Atkins dan Dyl, 1997:310). Bid-ask spread sebagai salah satu cerminan transaction cost yang lebih tinggi akan ditahan/dimiliki lebih lama oleh investor dalam waktu yang relatif pendek.

Bid-ask spread berhubungan terbalik dengan jumlah aktivitas perdagangan saham. Saham yang lebih banyak aktivitas perdagangannya (yaitu, volume perdagangan) cenderung memiliki spread yang rendah. Hubungan yang terbalik antarjumlah aktivitas perdagangan (atau nilai pasar) dan ukuran spread dapat dijelaskan dengan segera setelah diketahui bahwa spread yang ada adalah kompensasi bagi dealer yang memberikan investor likuiditas. Bid price adalah harga tertinggi yang ditawarkan investor yang akan membeli suatu saham, sedangkan ask price adalah harga terendah yang ditawarkan investor yang akan menjual suatu saham (Fitriyah, 2012). Spread merupakan selisih antara harga beli (bid price) tertinggi yang menyebabkan investor bersedia untuk membeli saham tertentu dengan harga jual (ask price) terendah yang menyebabkan investor bersedia menjualnya. Besarnya spread tergantung pada besarnya cost yang terjadi.

Menurut Sudana dan Intan (2008), penentuan besarnya spread oleh market maker merupakan kompensasi untuk menutupi 3 jenis biaya antara lain:

1. Inventory Holding Cost (Biaya Kepemilikan Saham) Biaya pemilikan saham menunjukkan trade-off antara memiliki terlalu banyak saham dan membeli sedikit saham. Banyak sedikitnya saham juga dapat ditunjukkan oleh lama tidaknya trader memegang saham tersebut. Apabila saham yang dimiliki sulit diperdagangkan, maka dengan terpaksa trader harus menahan dana yang tertanam pada saham dan menanggung opportunity cost. Opportunity cost merupakan bagian terbesar dari biaya pemilikan saham.

2. Order Processing Cost (Biaya Pesanan)

Biaya pemrosesan pesanan yaitu kompensasi bagi dealer atas jasanya menjalankan pesanan investor yang meliputi biaya administrasi, pelaporan, proses komputer, telepon, dan lain-lain. Sama halnya menurut Halim dan Hidayat (2000) biaya pesanan merupakan biaya dealer dalam mengatur perdagangan dan menyiapkan transaksi. Biaya pemrosesan pesanan ini antara lain administrasi, pelaporan, proses computer, telepon, dan lainnya.

3. Adverse Information Cost (Biaya Informasi)

Timbulnya biaya informasi asimetri disebabkan adanya dua pihak trader mempunyai dan mengakses informasi yang tidak sama. Pihak pertama adalah informed trader yang memiliki informasi superrior, dan pihak lain adalah uninformed trader yang memiliki informasi inferior. Informasi asimetri menyebabkan munculnya perilaku adverse selection yaitu investor yang mempunyai informasi superior akan melakukan aksi jual ketika investor lain yang memiliki sedikit informasi memasang harga bid terlalu tinggi. Sebaliknya, investor yang memiliki informasi inferior akan melakukan aksi beli ketika investor lain memiliki sedikit informasi memasang harga ask terlalu rendah, sehingga investor yang memiliki sedikit informasi akan mengalami risiko rugi.

\section{Closing Price}

Harga saham dikatakan sebagai indikator keberhasilan pengelolaan perusahaan, dimana kekuatan pasar ditunjukkan dengan terjadinya transaksi perdagangan saham perusahaan di pasar modal. Menurut Jogiyanto (2014), harga saham adalah harga yang ditetapkan dari suatu saham pada saat pasar saham sedang berlangsung dengan mempertimbangkan permintaan dan penawaran dari saham yang dimaksud.

Perubahan harga saham ditentukan berdasarkan penilaian investor terhadap perusahaan. Apabila perusahaan dipandang memiliki masa depan yang baik, dan diperkirakan akan berkembang pesat, maka investor tersebut memberikan penilaian yang tinggi terhadap saham perusahaan yang sedang dipertukarkan, demikian sebaliknya.

Menurut Widoatmojo, (2009:13) harga saham dapat dibedakan menjadi 3 (tiga) :

1. Harga nominal

Harga nominal merupakan harga yang tercantum dalam sertifikat saham yang ditetapkan oleh emiten untuk menilai setiap lembar saham yang dikeluarkan. Besarnya harga nominal memberikan arti penting saham karena deviden yang dibayarkan atas saham biasanya ditetapkan nilai nominal.

2. Harga perdana

Harga perdana merupakan harga pada waktu saham tersebut dicatat di bursa efek dalam rangka penawaran umum penjualan saham perdana yang disebut dengan IPO (Initial Public Offering). Harga saham pada pasar perdana biasanya ditetapkan oleh penjamin emisi (underwriter) dan emiten. Dengan demikian akan diketahui berapa harga saham emiten itu akan dijual kepada masyarkat.

3. Harga pasar

Harga pasar adalah harga jual dari investor yang satu dengan investor yang lain. Harga ini terjadi setelah saham tersebut dicatatkan di bursa efek. Transaksi disini tidak lagi melibatkan emiten dari penjamin emisi. Harga inilah yang disebut sebagai harga di pasar sekunder dan merupakan harga yang benarbenar mewakili harga perusahaan penerbitnya, karena pada transaksi di pasar sekunder, kecil sekali terjadi negosiasi harga antara investor dengan perusahaan penerbit. Harga yang setiap hari diumumkan di surat kabar atau media lain adalah harga pasar yang tercatat pada waktu penutupan (closing price) aktivitas di Bursa Efek Indonesia. 
Hal ini dapat terjadi jika harga saham turun yang disebabkan oleh penawaran yang tinggi, maka saham akan menawarkan return yang tinggi dibandingkan dengan saham yang lain sehingga investor akan tertarik untuk memperbanyak jumlah saham yang dimiliki sehingga biaya kepemilikan saham akan turun yang berarti mempersempit bid-ask spread.

\section{Trading Volume Activity}

Menurut Gunaasih dan Irfan (2015), Trading volume activity merupakan instrumen yang digunakan untuk mengamati serta mengukur reaksi pasar modal terhadap informasi atau peristiwa yang terjadi di pasar modal. Informasi atau peristiwa tertentu dapat memicu pergerakan saham di pasar modal yang akan mempengaruhi penawaran dan permintaan saham.

Dalam membuat keputusan investasinya, seorang investor yang rasional akan mempertimbangkan risiko dan tingkat keuntungan yang diharapkan. Untuk itu investor seharusnya melakukan analisis sebelum menentukan saham yang akan mereka beli. Dalam melakukan analisis, investor memerlukan informasi. Adanya informasi yang dipublikasikan akan merubah keyakinan para investor yang dilihat dari reaksi pasar. Salah satu reaksi pasar tersebut adalah volume perdagangan saham.

Volume perdagangan saham merupakan ukuran besarnya saham tertentu yang diperdagangkan, mengindikasikan kemudahan dalam memperdagangkan saham tersebut. Besarnya variabel volume perdagangan diketahui dengan mengamati kegiatan perdagangan yang dapat dilihat melalui indikator aktivitas perdagangan Trading Volume Activity (TVA).

Perdagangan suatu saham yang aktif, yaitu dengan volume perdagangan yang besar, menunjukkan bahwa saham tersebut digemari oleh investor yang berarti saham tersebut aktif diperdagangkan. Ketika aktif diperdagangkan, dealer cenderung ingin menaikkan keuntungan yang didapatnya dengan cara menaikkan harga bid dan harga ask sehingga spread yang didapat akan semakin besar.

\section{Volatilitas Return Saham}

Menurut Engle (2001), Volatilitas return saham adalah volatilitas dari pengembalian harga saham yang mempresentasikan risio dari return harga saham. Volatilitas harga pada waktu ke-t diduga pada waktu t-1 sehingga umumnnya diukur dengan strandar deviasi.

Volatilitas didefinisikan sebagai fluktuasi dari return suatu sekuritas atau portofolio dalam suatu periode tertentu. Volatilitas return saham menggambarkan naik turunnya saham selama kurun waktu tertentu. Selain itu, volatilitas return saham juga mencerminkan tingkat ketidakpastian atau risiko atas besaran perubahan nilai suatu sekuritas. Dengan melihat pergerakan volatilitas return saham akan membuat investor dapat melihat seberapa besar risiko yang akan diterima apabila menanamkan saham pada perusahaan yang diinvestasikannya.

Volatilitas merupakan besarnya jarak naik dan turunnya harga saham atau valas. Volatilitas berperan pada return investasi, jika saham memiliki return yang tinggi maka saham tersebut mempunyai risiko yang tinggi pula. Volatilitas juga dapat diartikan sebagai varians dinamik (conditional variance) dari sebuah asset. Analisis volatilitas berguna dalam pembentukan portofolio, manajemen risiko dan pembentukan harga. Volatilitas bisa diukur dengan simpang baku, sehingga dipersepsikan pula sebagai risiko. Semakin tinggi tingkat volatilitas, semakin tinggi pula tingkat ketidakpastian dari imbal hasil return saham yang dapat diperoleh (Tim Studi Volatilitas, 2011).

Risiko dalam investasi saham biasa juga harus dipertimbangkan oleh investor. Return dan risiko mempunyai hubungan yang positif, semakin besar risiko yang harus ditanggung, semakin besar return yang harus dikompensasikan. Risiko merupakan besarnya penyimpangan antara tingkat pengembalian yang diharapkan (expected return) dengan tingkat pengembalian pengembalian aktual (actual return).

Apabila risiko dinyatakan sebagai seberapa jauh hasil yang diperoleh dapat menyimpang dari hasil yang diharapkan, maka digunakan ukuran penyebaran. Alat statistik yang digunakan sebagai ukuran penyebaran tersebut adalah varians atau deviasi standar. Semakin besar nilainya, berarti semakin besar penyimpangannya (berarti risiko semakin tinggi).

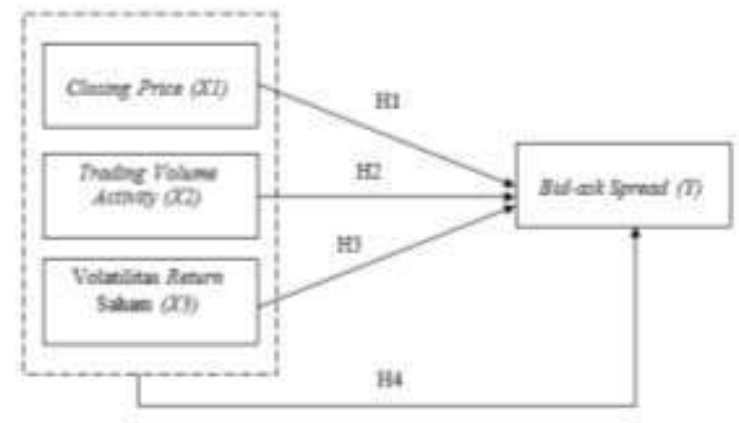

Gambar 1. Kerangka Pemikiran Teoritis

\section{HIPOTESIS PENELITIAN}

Closing price, trading volume activity dan volatilitas return saham saling berkaitan sebagai indikator untuk mengetahui pengaruh besar kecilnya bid-ask spread. Berdasarkan uraian diatas dapat dirumuskan sebagai berikut:

$\mathrm{H}_{1}$ : closing price berpengaruh signifikan terhadap bid-ask spread.

$\mathrm{H}_{2}$ : trading volume activity berpengaruh signifikan terhadap bid-ask spread.

$\mathrm{H}_{3}$ : volatilitas return saham berpengaruh signifikan terhadap bid-ask spread.

$\mathrm{H}_{4}$ : closing price, trading volume activity dan volatilitas return saham berpengaruh signifikan terhadap bidask spread.

\section{METODE}

\section{Populasi dan Sampel}

Populasi yang digunakan dalam penelitian ini adalah perusahaan yang terdaftar di indeks LQ45 di Bursa Efek Indonesia (BEI) tahun 2017. Seluruh perusahaan dipilih 
karena indeks LQ-45 ini memberikan gambaran yang akurat akan perubahan nilai pasar dari seluruh saham yang aktif diperdagangkan di Bursa Efek Indonesia (BEI) (Fakhuddin dan Hardianto, 2001:203).

penelitian ini menggunakan metode purposive sampling sebagai teknik pengambilan sampel, yaitu pengambilan datanya disesuaikan dengan kriteria-kriteria yang telah ditentukan sebelumnya. Kriterianya adalah sebagai berikut:

1. Saham terdaftar pada indeks LQ45 secara konsisten sepanjang tahun 2017.

2. Saham yang tidak melakukan stock split.

3. Saham yang memiliki hari bursa sebanyak 238 hari.

Berdasarkan kriteria dalam penentuan sampel, terpilih 7.854 sampel dalam penelitian ini yang terdiri dari 33 perusahaan LQ45 dengan hari bursa sebanyak 238 hari.

\section{Metode Pengumpulan Data}

Metode pengumpulan data dalam penelitian ini menggunakan dokumentasi data sekunder yaitu jumlah saham beredar closing price, volume perdagangan, bid price, dan ask price dalam bentuk ringkasan saham yang dipublikasikan oleh www.idx.co.id untuk tahun 2017.

\section{Pengukuran Variabel}

\section{Variabel Independen (Variabel Bebas)}

1. Closing price

Perhitungan harga saham pada penelitian ini menggunakan harga penutupan (closing price) masing-masing saham i pada penutupan bursa hari ke t.

2. Trading volume activity

Rumus volume perdagangan saham untuk saham i pada hari i.

$$
\mathrm{TVA}=\frac{\text { Volume Perdagangan }}{\text { Saham yang beredar pada waktu } \mathrm{t}}
$$

Keterangan :

TVA $=$ Rasio volume perdagangan saham

Volume perdagangan $=$ jumlah saham yang ditransaksikan

Saham i yang beredar = saham perusahaan $\mathrm{i}$ yang beredar

3. Volatilitas return saham

Volatilitas return saham pada penelitian ini diproksikan dengan risiko saham. Rumus tingkat risiko return saham :

Keterangan :

$$
\operatorname{Risk}_{\mathrm{t}}=\sqrt{\sum_{\mathrm{i}=1}^{\mathrm{n}} \frac{\left(\mathrm{R}_{\mathrm{t}} 1-\mathrm{R}\right)^{2}}{\mathrm{n}-1}}
$$

Rt 1 = return saham pada hari ke-t

$\mathrm{R} \quad=$ rata-rata return

$\mathrm{n} \quad=$ jumlah observasi

\section{Variabel Dependen (Variabel Terikat)}

Variabel dependen adalah bid-ask spread. Bid-ask spread merupakan selisih antara ask price dan bid price. Investor memperolah keuntungan dari spread kedua harga tersebut (Jones, 2007:108). Perhitungan bid-ask spread:

Keterangan $=$

$$
\text { Spread }_{i t}=\left[\sum_{t=1}^{N} \frac{\left(\operatorname{ask}_{i t}-b_{i d}\right)}{\frac{1}{2}\left(\text { ask }_{\text {it }}+\text { bid }_{i t}\right)}\right]
$$

Spread $_{\text {it }}=$ rata-rata bid-ask spread dari saham i selama tahun $\mathrm{t}$

$A s k_{\text {it }}=$ harga jual terendah yang menyebabkan investor setuju untuk menjual saham i pada hari $\mathrm{t}$

$B i d_{\text {it }}=$ harga beli tertinggi yang menyebabkan investor setuju untuk membeli saham i pada hari t

\section{Instrumen Penilaian}

Penelitian ini dilakukan dengan pengujian statistik untuk mengetahui variabel mempunyai pengaruh yang signifikan terhadap bid-ask spread.

\section{Metode Analisis Data}

Pada penelitian ini menggunakan Microsoft Office Excel dan Eviews 10 untuk pengolahan data dan pengujian hipotesis. Pengolahan dan perhitungan data sekunder untuk variabel bebas akan diolah dan dihitung dengan menggunakan Microsoft office excel. Sementara pengolahan data sekunder untuk variabel terikat dan estimasi regresi data panel untuk menguji hipotesis menggunakan eviews 10.

\section{HASIL DAN PEMBAHASAN}

\section{Estimasi Model Regresi Data Panel}

Estimasi regresi data panel akan diduga menggunakan tiga metode yang ada dalam regresi data panel, yaitu:

a. Common Effect

\begin{tabular}{ccccc}
\hline \hline Variable & Coefficient & Std. Error & t-Statistic & Prob. \\
\hline \hline C & 0.002638 & 0.000274 & 9.641202 & 0.0000 \\
$\mathrm{CP}^{\wedge} 2$ & 0.148998 & 0.178269 & 0.835806 & 0.4033 \\
$\mathrm{TVA}^{\wedge} 2$ & 12.60733 & 1.843846 & 6.837519 & 0.0000 \\
$\mathrm{R}_{\mathrm{VOL}}{ }^{\wedge} 2$ & 985.2926 & 39.69606 & 24.82092 & 0.0000 \\
\hline \hline
\end{tabular}

b. Fixed Effect

\begin{tabular}{ccccc}
\hline \hline Variable & Coefficient & Std. Error & t-Statistic & Prob. \\
\hline \hline C & 0.000918 & 0.000838 & 1.094557 & 0.2737 \\
CP$^{\wedge} 2$ & 2.538639 & 1.177756 & 2.155488 & 0.0312 \\
TVA $^{\wedge} 2$ & 15.49594 & 1.976247 & 7.841096 & 0.0000 \\
R_VOL$_{-} 2$ & 1001.125 & 41.03077 & 24.39938 & 0.0000 \\
\hline \hline
\end{tabular}

c. Random Effect

\begin{tabular}{ccccc}
\hline \hline Variable & Coefficient & Std. Error & t-Statistic & Prob. \\
\hline \hline C & 0.002638 & 0.000273 & 9.653391 & 0.0000 \\
CP$^{\wedge} 2$ & 0.148998 & 0.178044 & 0.836863 & 0.4027 \\
TVA $^{\wedge}$ & 12.60733 & 1.841517 & 6.846163 & 0.0000 \\
R_VOL^2 & 985.2926 & 39.64593 & 24.85230 & 0.0000 \\
\hline \hline
\end{tabular}




\section{Pemilihan Estimasi Model Regresi Data Panel}

Untuk menguji permodelan regresi data panel ketiga estimasi model regresi dengan melakukan Uji Chow, Uji Hausman dan Uji Langrange Multiplier yang ditunjukan untuk menentukan apakah model data panel dapat terbaik diantara common effect, fixed effect dan random effect (Widarjono, 2013: 362-365).

a. Uji Chow

\begin{tabular}{lrrr}
\hline \hline Effects Test & Statistic & d.f. & Prob. \\
\hline \hline Cross-section F & 1.620675 & $(32,7818)$ & 0.0149 \\
Cross-section Chi- & 51.928358 & 32 & 0.0144 \\
square & & & \\
\hline \hline
\end{tabular}

Berdasarkan tabel diatas, diperoleh nilai $p$ value (Prob.) pada cross-section sebesar 0.0149 dan chi-square sebesar 0.0144 sehingga $<\alpha=0.05$ maka $\mathrm{H}_{0}$ ditolak yang artinya model fixed effect lebih baik digunakan daripada model common effect

b. Uji Hausman

\begin{tabular}{cccc}
\hline \hline Test Summary & Chi-Sq. Statistic & $\begin{array}{c}\text { Chi-Sq. } \\
\text { d.f. }\end{array}$ & Prob. \\
\hline \hline Cross-section random & 30.058031 & 3 & 0.0000 \\
\hline \hline
\end{tabular}

Berdasarkan tabel diatas, diperoleh nilai $p$ value (Prob.) yaitu $0.0000>\alpha=0.05$, maka $\mathrm{H}_{0}$ ditolak yang artinya model fixed effect lebih baik digunakan daripada model random effect.

\section{c. Uji Langrange Multiplier}

Uji LM-Test bertujuan untuk mengetahui pilihan model yang lebih baik digunakan antara common effect dan random effect. Berdasarkan uji Chow dan Uji Hausman, dihasilkan model regresi data panel yang terpilih yaitu fixed effect model. Oleh karena itu, LM-Test tidak perlu dilakukan karena fixed effect model lebih baik dari common effect model dan random effect model pada Uji Chow dan Uji Hausman.

\section{Uji Hipotesis}

a. Uji Parsial (Uji t)

\begin{tabular}{ccccc}
\hline \hline Variable & Coefficient & Std. Error & t-Statistic & Prob. \\
\hline \hline $\mathrm{C}$ & 0.000918 & 0.000838 & 1.094557 & 0.2737 \\
$\mathrm{CP}^{\wedge} 2$ & 2.538639 & 1.177756 & 2.155488 & 0.0312 \\
$\mathrm{TVA}^{\wedge} 2$ & 15.49594 & 1.976247 & 7.841096 & 0.0000 \\
$\mathrm{R}_{-} \mathrm{VOL}^{\wedge} 2$ & 1001.125 & 41.03077 & 24.39938 & 0.0000 \\
\hline \hline
\end{tabular}

Berdasarkan tabel diatas, t-statistic variabel closing price adalah 2.155488 lebih besar dari $\mathrm{t}$ kritis (tabel) yaitu 1.960 dan p-value pada variabel closing price sebesar 0.0312 lebih kecil dari $\alpha=$ $0,05(5 \%)$ sehingga $\mathrm{H}_{0}$ ditolak dan $\mathrm{H}_{1}$ diterima. Hal ini menunjukkan bahwa closing price memiliki pengaruh signifikan terhadap bid-ask spread. Harga saham cenderung senantiasa naik dalam tiap transaksinya sehingga menghasilkan return saham yang tinggi. Hal ini mengindikasikan bahwa saham tersebut digemari oleh para investor. Keadaan ini juga senantiasa membuat dealer tidak langsung melepas saham tetapi saham tersebut di tahan terlebih dahulu sampai pada waktu tertentu, sehingga semakin lama saham tersebut berada di tangan dealer maka akan menimbulkan lebih besarnya bid-ask spread dikarenakan akan menyerap lebih banyak biaya kepemilikan saham yang ditanggung oleh dealer.

Berdasarkan tabel diatas, $\mathrm{t}$-statistic trading volume activity adalah 7.841096 lebih besar dari t kritis (tabel) yaitu 1.960 dan p-value pada variabel trading volume activity menunjukkan hal yang sama yaitu sebesar 0.0000 lebih kecil dari $\alpha=0,05$ (5\%) sehingga $\mathrm{H}_{0}$ ditolak dan $\mathrm{H}_{2}$ diterima. Hal ini menunjukkan bahwa trading volume activity memiliki pengaruh signifikan terhadap bid-ask spread. Trading volume activity merupakan suatu instrumen yang dapat digunakan untuk melihat reaksi pasar modal terhadap informasi melalui parameter pergerakan aktivitas volume perdagangan di pasar. Ketika dealer mengetahui bahwa suatu saham aktif diperdagangkan di pasar modal, maka dealer berkesempatan untuk mengambil keuntungan dengan memanfaatkan tingkat spread tersebut. Perdagangan suatu saham yang tinggi dengan volume perdagangan yang besar, dapat menyebabkan investor juga bersedia membeli saham dengan harga yang lebih tinggi, dengan begitu dealer akan menaikkan keuntungan dengan menaikkan spread saham.

Berdasarkan tabel diatas, t-statistic volatilitas return saham adalah 24.39938 lebih besar dari $\mathrm{t}$ kritis (tabel) yaitu 1.960 dan p-value pada variabel volatilitas return saham menunjukkan hal yang sama yaitu sebesar 0.0000 lebih kecil dari $\alpha=0,05$ (5\%) sehingga $\mathrm{H}_{0}$ ditolak dan $\mathrm{H}_{3}$ diterima. Hal ini menunjukkan bahwa volatilitas return saham memiliki pengaruh signifikan terhadap bid-ask spread. Risiko saham sangat mempengaruhi keputusan investor dalam pengambilan keputusannya. Hal tersebut dikarenakan semakin besar risiko yang harus ditanggung, semakin besar return yang harus dikompensasikan. Semakin tinggi volatilitas return saham maka akan semakin tinggi pula nilai spread relatif saham. Volatilitas return saham secara langsung dapat mengukur risiko saham dan secara tidak langsung dapat mengukur tingkat asimetri informasi antarpelaku pasar. Semakin tinggi tingkat asimetri informasi, berarti semakin tinggi pula komponen adverse selection dalam bid-ask spread. 


\section{Saran}

Berdasarkan hasil penelitian, berikut ini saran yang diberikan oleh penulis.

1. Bagi Investor

Investor sebaiknya lebih mempertimbangkan untuk berinvestasi jangka panjang karena keuntungan yang akan didapat akan lebih banyak, selain itu, investor harus memperhatikan closing price, trading volume activity dan volatilitas return saham ketika akan membeli atau menjual saham supaya tidak membayar spread yang terlalu tinggi.

2. Bagi Perusahaan

Perusahaan disarankan untuk memastikan informasi tentang perusahaan selalu stabil. Informasi yang stabil dan positif akan mendorong persaingan penawaran dan permintaan investor sehingga terbentuk bid-ask spread yang kecil.

3. Bagi Peneliti Selanjutnya

Bagi peneliti dengan topik sejenis disarankan untuk melakukan kajian lebih mendalam dengan melakukan penelitian pada saham yang berbeda (sektor/indeks sahamnya) sehingga untuk mendapatkan penelitian yang lebih bervariasi. Selain itu, sebaiknya peneliti selanjutnya dapat menambah variabel lain (return saham, dividend yield, likuiditas, leverage dan lainnya) sehingga dapat memperkuat hasil untuk penelitian selanjutnya

\section{DAFTAR PUSTAKA}

Atkins, A.B. and E.A Dyl. 1997. Transaction cost and holding period for common stocks. The Journal of Finance. 52 (1):309-325.

Bursa Efek Indonesia, Buku Panduan Indeks Harga Saham Gabungan Bursa Efek Indonesia. Jakarta: Indonesia Stock Exchange, 2010.

Gunaasih, dan Nursasmito, Irfan, (2015), The Evaluation of Non-Economic Event Towards the LQ-45 Index in Indonesia Stock Exchange by Using Event Study Method, Integrative Busines \& Economic Research, Vol. 4, No. 2.

Halim, Abdul dan Nasuhi Hidayat, 2000. Studi Empiris Tentang Pengaruh Volume Perdagangan dan Return Terhadap Bid-Ask Spread Saham Industri Rokok di BEJ dengan Model Korelasi Kesalahan, Jurnal Riset Akuntansi Indonesia. Vol, 3 hal.69-85.

Hartono, Jogiyanto. 2003. Teori Portofolio dan Analisis Investasi. Edisi Ketiga. Yogyakarta: Penerbit BPFE.

2014. Teori Portofolio dan Analisis Investasi. Edisi kesembilan. Yogyakarta : BPFE 2017. Teori Portofolio dan Analisis Investasi. Edisi 11. Yogyakarta: Penerbit BPFE.
Jones. 2007. Investments, Tenth Edition. New York: John Wiley and Son.

Nany, M. 2003. Analisis pengaruh harga saham, return saham, varian return saham, earnings dan volume perdagangan saham terhadap bid ask spread sebelum dan sesudah pengumuman laporan keuangan (studi empiris pada Saham LQ45 di Bursa Efek Jakarta). Jurnal Perspektif, 9(1): 23-31.

Sudana, I Made dan Intan, 2008. Leverage Keuangan dan Likuiditas Saham Perusahaan Manufaktur yang Terdaftar Di Bursa Efek Jakarta, Jurnal Manajemen Teori dan Terapan, Universitas Airlangga, Palembang.

Tim Studi Volatilitas Pasar Modal Indonesia dan Perekonomian Dunia. 2011. Laporan Studi Volatilitas Pasar Modal Indonesia dan Perekonomian Dunia. Kementerian Keuangan Republik Indonesia : Badan Pengawas Pasar Modal dan Lembaga Keuangan.

Widarjono, Agus. 2006. Ekonometrika Untuk Analisis Ekonomi dan Keuangan. Jakarta: UI.

Widoatmodjo, Sawidji. 2009. Pasar Modal Indonesia. Bogor: Ghalia Indonesia. 